\title{
Japanese eel Anguilla japonica do not assimilate nutrition during the oceanic spawning migration: evidence from stable isotope analysis
}

\author{
Seinen Chow ${ }^{1, *}$, Hiroaki Kurogi $^{1}$, Satoshi Katayama ${ }^{1}$, Daisuke Ambe ${ }^{2}$, \\ Makoto Okazaki ${ }^{2}$, Tomowo Watanabe ${ }^{2}$, Tadafumi Ichikawa ${ }^{2}$, Masashi Kodama ${ }^{2}$, \\ Jun Aoyama ${ }^{3}$, Akira Shinoda ${ }^{3}$, Shun Watanabe ${ }^{3}$, Katsumi Tsukamoto ${ }^{3}$, Sachie Miyazaki ${ }^{3}$, \\ Shingo Kimura ${ }^{3}$, Yoshiaki Yamada ${ }^{4}$, Kazuharu Nomura ${ }^{5}$, Hideki Tanaka ${ }^{5}$, \\ Yukinori Kazeto ${ }^{5}$, Kazuhiro Hata ${ }^{6}$, Takeshi Handa ${ }^{6}$, Atsushi Tawa ${ }^{7}$, Noritaka Mochioka ${ }^{7}$ \\ ${ }^{1}$ National Research Institute of Fisheries Science, 6-3-1 Nagai, Yokosuka, Kanagawa 238-0316, Japan \\ ${ }^{2}$ National Research Institute of Fisheries Science, 2-12-4 Fukuura, Yokohama, Kanagawa 236-8648, Japan \\ ${ }^{3}$ Ocean Research Institute, The University of Tokyo, 1-15-1 Minamidai, Tokyo 164-8639, Japan \\ ${ }^{4}$ IRAGO Institute, 377 Ehima-Shinden Atsumi-Cho, Aichi 441-3605, Japan \\ ${ }^{5}$ National Research Institute of Aquaculture, 422-1 Nakatsu-Hamaura, Mie 516-0193, Japan \\ ${ }^{6}$ National Fisheries University, 2-7-1 Nagata-Honmachi, Shimonoseki, Yamaguchi 759-6595, Japan \\ ${ }^{7}$ Kyushu University, 6-10-1 Hakozaki, Fukuoka 812-8581, Japan
}

\begin{abstract}
During 2008 and 2009, a total of 12 adult Japanese eels Anguilla japonica were captured in the southern part of the West Mariana Ridge, the presumed spawning area. We compared the stable carbon and nitrogen isotope ratios $\left(\delta^{13} \mathrm{C}\right.$ and $\left.\delta^{15} \mathrm{~N}\right)$ between the 'Mariana silvers' (terminal phase) and those of yellow and silver eels caught in rivers, lakes and coastal areas of Japan (initial phase). Profiles of stable isotope signatures between the initial and terminal phases were similar; both characteristically had a wide range for $\delta^{13} \mathrm{C}(-24.9$ to $-12.0 \%$ and -20.5 to $-11.3 \%$ for the initial and terminal phases, respectively) and $\delta^{15} \mathrm{~N}$ (6.5 to $18.4 \%$ and 9.0 to $18.1 \%$, respectively). Mesopelagic fishes, including several other anguillid species caught near the West Mariana Ridge, characteristically had a very narrow range of $\delta^{13} \mathrm{C}(-16.9$ to $-15.3 \%)$ and a wide but lower range of $\delta^{15} \mathrm{~N}(5.3$ to $11.1 \%$ ) than the Japanese eels. The very similar profiles in stable isotopic signatures between the initial and terminal phase eels, distinct from those of Mariana mesopelagic fishes, indicate that Japanese eels do not assimilate nutrition from the marine environment during long (ca. 6 mo) spawning migration and retain the initial isotopic values of where they ceased feeding.
\end{abstract}

KEY WORDS: $\delta^{13} \mathrm{C} \cdot \delta^{15} \mathrm{~N} \cdot$ Starvation $\cdot$ Spawning migration $\cdot$ Anguilla japonica

Resale or republication not permitted without written consent of the publishe

\section{INTRODUCTION}

It has been presumed that silver stage freshwater eels of the genus Anguilla do not feed during the oceanic migration and are totally dependent on their fat stores to fuel the migration and gonad development (Tsukamoto 2009), since the alimentary tracts of silver eels caught in rivers and coastal areas are morphologically and histologically degenerating (Pankhurst \& Sorensen 1984, Durif et al. 2005). Hence, freshwater eels have to accomplish very long oceanic migration without feeding and being reliant on stored reserves: 2000-3000 km for the Japanese and American eels (Anguilla japonica and Anguilla rostrata, respectively) and 5000-6000 km for the European eel Anguilla anguilla (Tsukamoto et al. 2002, Aoyama 2009). However, Svedäng \& Wickström (1997) suggested that silver stage eels may arrest maturation and resume feeding during migration, since they observed many silvering female European eels with fat contents that 
were insufficient to reach the Sargasso Sea. Some tagged and released silver stage European eels were recaptured $>4$ yr later (Westin 1990); regeneration of alimentary tracts and feeding has also been observed in male silver stage eels (Dollerup \& Graver 1985). On the other hand, Van Ginneken \& Van den Thillart (2000) showed that the energy cost for the European eels to reach the Sargasso Sea may theoretically be lower than expected. In fact, laboratory experiments successfully demonstrated that European eels are capable of swimming over a distance of $5500 \mathrm{~km}$ without resting and feeding (Van Ginneken et al. 2005, 2007). Yet, the swim trial alone does not assure absence of feeding during the spawning migration, and it would be inevitable that freshwater eels caught in the spawning area would be analyzed too.

Research cruises were performed in June and August 2008 and June 2009, and a total of 12 adult Japanese eels ( 6 males and 6 females) were captured by a large mid-water trawl net in the southern part of the West Mariana Ridge (Chow et al. 2009, H. Kurogi unpubl. data), the supposed spawning area (Tsukamoto et al. 2003, Tsukamoto 2006). We compared the stable carbon and nitrogen isotope ratios $\left(\delta^{13} \mathrm{C}\right.$ and $\delta^{15} \mathrm{~N}$, indicators of food source) between these 'Mariana silvers' (terminal phase) and the Japanese eels at yellow and silver stages collected in rivers, lakes and coastal areas of Japan (initial phase) to ascertain the presence/absence of feeding during the reproductive migration.

\section{MATERIALS AND METHODS}

Fish samples. The catch localities and biological data of the fish samples used in the present study are presented in Fig. 1 and Table 1. A total of 72 adult Japanese eels Anguilla japonica at the initial phase were collected from 10 locales in Japan (Fig. 1, positions 1-10), which were classified into 37 yellow and 35 silver stage eels (Okamura et al. 2007). All initial phase eels (IPE) were adult $(60.5 \pm 13.0 \mathrm{~cm}$ in body length) and were either caught downstream and in river estuaries, or in coastal lakes and other coastal areas. Leptocephali of Japanese eel (AJL) and a conger eel (Conger sp.: CON) were collected in the south of the Ryukyu Archipelago (Fig. 1, position 11). Terminal phase silver eels (TPE) were caught in the southern part of the West Mariana Ridge (Fig. 1, position 12). Body length of these 12 TPE ranged from 44.7 to $76.7 \mathrm{~cm}$ (mean of

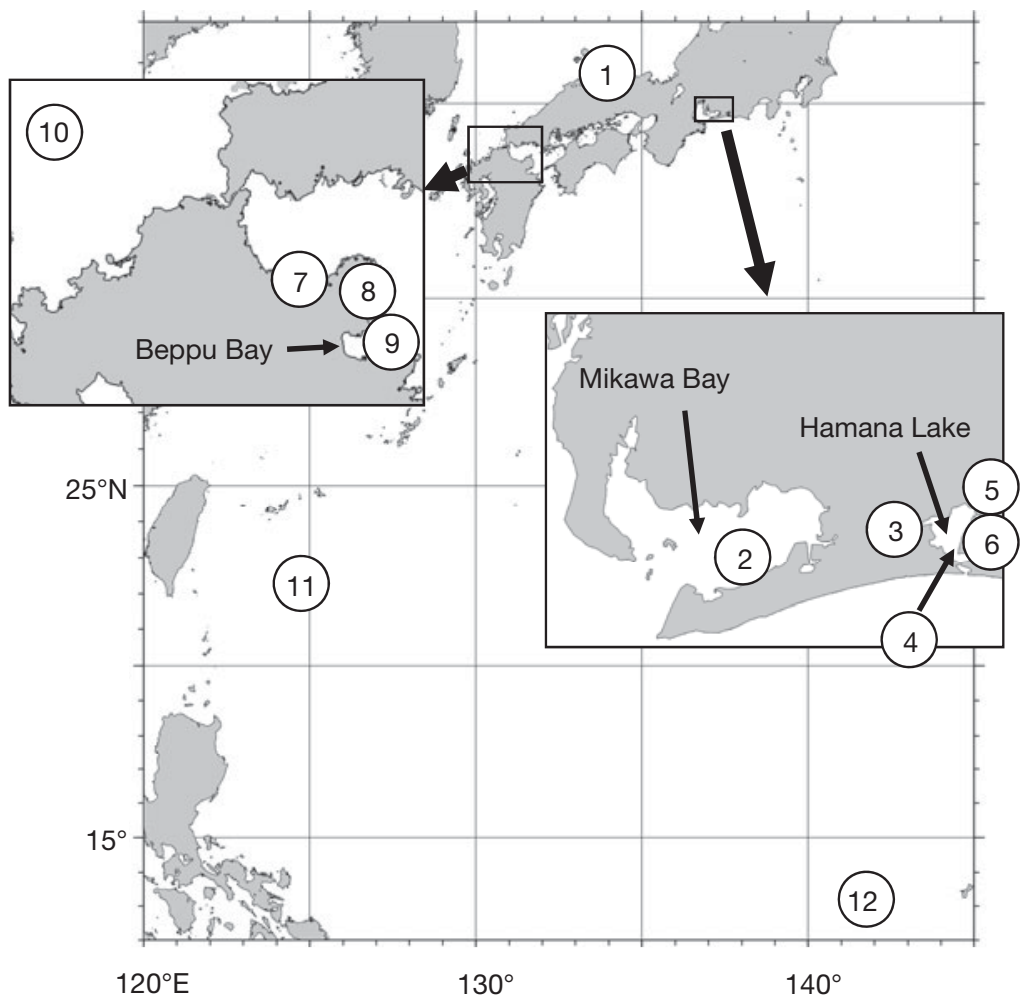

Fig 1. Locations of fish samples collected. (1) Koyama River, (2) Mikawa Bay, (3) Irideohta River, (4) Hamana Lake, (5) Miyakoda River, (6) Sanaru Lake, (7) Yakkan River, (8) Aki River, (9) Beppu Bay, (10) Okinoshima Is., est Pacific $\left(26^{\circ} 00^{\prime} \mathrm{N}\right.$ and $\left.126^{\circ} 30^{\prime}-127^{\circ} 00^{\prime} \mathrm{E}\right),(12)$ southern part of the West Mariana Ridge (see Chow et al. 2009)

$67.4 \pm 9.3 \mathrm{~cm}$ for female, $\mathrm{n}=6 ; 52.2 \pm 7.2 \mathrm{~cm}$ for male, $\mathrm{n}=6$ ). Juveniles and adults of 8 mesopelagic fishes, Derichthys sp. (longneck eel: KUB), Dolichosudis fuliginosa (barracudina: HSN), Emmelichthys struhsakeri (rover: RSC), Lepidocybium flavobrunneum (escolar: ABS), Nemichthys sp. (snipe eel: SIG), Ruvettus pretiosus (oilfish: BRM), Scombrolabrax heterolepis (longfin escolar: MKK) and Serrivomer sp. (sawtooth eel: SERA) and leptocephali of a sawtooth eel (Serrivomer sp.: SERL), were collected where the TPE were caught (Fig. 1, position 12).

Stable isotope analysis. Dorsal muscle tissues dissected from the central part of the body were lyophilized and homogenized to a fine powder, and then defatted using 2:1 or 1:1 chloroform-methanol solution (v/v) and centrifugation (Folch et al. 1957). Four IPE samples (IPE3-6) of Hamana Lake system were defatted using 2:1 chloroform-methanol solution, and the other samples using 1:1 solution (v/v). The defatted samples were oven-dried and sample aliquots (ca. $0.8 \mathrm{mg}$ ) were placed in tin containers. $\delta^{13} \mathrm{C}$ and $\delta^{15} \mathrm{~N}$ were analyzed using an EA-1108 elemental analyzer (Carlo Erba) coupled with an isotope ratio mass spectrometer (Finnigan Mat ConFlo II, Mat 252). The 
Table 1. Collection data of freshwater eel Anguilla japonica and other marine fish species used in this study. Catch locality: see Fig. 1 for more specific location. Parentheses: no. of ind. at silver (s) or yellow (y) stages; (-) no information available

\begin{tabular}{|c|c|c|c|c|c|c|c|c|}
\hline Species & ID & $\begin{array}{l}\text { Catch } \\
\text { locality }\end{array}$ & Fig. 1 & Stage & Date & $\mathrm{n}$ & $\begin{array}{c}\text { Body length } \\
(\mathrm{cm} \pm \mathrm{SD})\end{array}$ & Sex \\
\hline \multicolumn{9}{|l|}{ Anguilliformes } \\
\hline \multirow[t]{12}{*}{ Anguilla japonica } & IPE1 & Koyama River & 1 & Adult (1s, 3y) & $\begin{array}{c}\text { Jun 2007, } 2008 \\
\text { Nov } 2008\end{array}$ & 4 & $66.1 \pm 15.4$ & - \\
\hline & IPE2 & Mikawa Bay & 2 & Adult (1s) & Dec 2008 & 1 & 69.0 & 10 \\
\hline & IPE3 & Irideohta River & 3 & Adult (7y) & Sep, Nov 2007 & 7 & $61.0 \pm 5.7$ & $50,20^{7}$ \\
\hline & IPE4 & Hamana Lake & 4 & Adult $(2 \mathrm{~s}, 4 \mathrm{y})$ & Nov 2007 & 6 & $57.5 \pm 6.7$ & $50,10^{7}$ \\
\hline & IPE5 & Miyakoda River & 5 & Adult (11s, 9y) & Sep, Nov 2007 & 20 & $70.5 \pm 7.9$ & $180,20^{\prime}$ \\
\hline & IPE6 & Sanaru Lake & 6 & Adult (4y) & Sep, Nov 2007 & 4 & $66.8 \pm 2.7$ & 4 우 \\
\hline & IPE7 & Yakkan River & 7 & Adult $(11 \mathrm{~s}, 10 \mathrm{y})$ & Oct-Dec 2008 & 21 & $49.0 \pm 13.8$ & - \\
\hline & IPE8 & Aki River & 8 & Adult (3s) & Oct, Dec 2008 & 3 & $52.0 \pm 7.6$ & - \\
\hline & IPE9 & Beppu Bay & 9 & Adult (3s) & Dec 2008 & 3 & $63.4 \pm 2.2$ & 30 \\
\hline & IPE10 & Okinoshima Isl. & 10 & Adult (3s) & Dec 2008 & 3 & $69.9 \pm 8.0$ & $3 \overbrace{}^{+}$ \\
\hline & AJL & NW Pacific ${ }^{\mathrm{a}}$ & 11 & Larva & Oct 2005 & 5 & $5.0 \pm 0.4$ & - \\
\hline & TPE & $\mathrm{WMR}^{\mathrm{b}}$ & 12 & Adult (12s) & $\begin{array}{l}\text { Jun, Aug } 2008 \\
\text { Jun } 2009\end{array}$ & 12 & $52.9 \pm 14.4$ & $6 \%, 60^{7}$ \\
\hline Conger sp. & $\mathrm{CON}$ & NW Pacific ${ }^{\mathrm{a}}$ & 11 & Larva & Oct 2005 & 4 & $3.4 \pm 1.4$ & - \\
\hline Derichthys sp. & KUB & $\mathrm{WMR}^{\mathrm{b}}$ & 12 & Adult & Aug 2008 & 3 & $29.6 \pm 7.3$ & - \\
\hline Nemichthys sp. & SIG & $\mathrm{WMR}^{\mathrm{b}}$ & 12 & Adult & Aug 2008 & 3 & $65.4 \pm 6.4$ & - \\
\hline Serrivomer sp. & SERA & $\mathrm{WMR}^{\mathrm{b}}$ & 12 & Adult & Aug 2008 & 3 & $39.9 \pm 16.1$ & - \\
\hline Serrivomer sp. & SERL & $\mathrm{WMR}^{\mathrm{b}}$ & 12 & Larva & Aug 2008 & 2 & $4.6 \pm 2.2$ & - \\
\hline \multicolumn{9}{|l|}{ Aulopiformes } \\
\hline Dolichosudis fuliginosa & HSN & $\mathrm{WMR}^{\mathrm{b}}$ & 12 & Adult & Jun 2008 & 5 & $30.7 \pm 2.8$ & - \\
\hline \multicolumn{9}{|l|}{ Perciformes } \\
\hline Emmelichthys struhsakeri & RSC & $\mathrm{WMR}^{\mathrm{b}}$ & 12 & Juvenile & Jun 2008 & 4 & $9.7 \pm 1.8$ & - \\
\hline Lepidocybium flavobrunneum & ABS & $\mathrm{WMR}^{\mathrm{b}}$ & 12 & Juvenile & Jun 2008 & 8 & $12.2 \pm 6.4$ & - \\
\hline Ruvettus pretiosus & BRM & $\mathrm{WMR}^{\mathrm{b}}$ & 12 & Juvenile & Jun 2008 & 2 & $13.8 \pm 4.0$ & - \\
\hline Scombrolabrax heterolepis & MKK & $\mathrm{WMR}^{\mathrm{b}}$ & 12 & Juvenile & Jun 2008 & 7 & $11.8 \pm 3.6$ & - \\
\hline
\end{tabular}

isotope ratios were expressed as per mille (\%) deviation from international standard (i.e. the Vienna Pee Dee Belemnite for carbon and air $\mathrm{N}_{2}$ for nitrogen), in which $\delta^{13} \mathrm{C}$ or $\delta^{15} \mathrm{~N}=\left(R_{\text {sample }} / R_{\text {standard }}-1\right) \times 1000$, where $R$ is ${ }^{13} \mathrm{C} /{ }^{12} \mathrm{C}$ or ${ }^{15} \mathrm{~N} /{ }^{14} \mathrm{~N}$. Instrumental precision was $0.2 \%$. The Mann-Whitney $U$-test was used to compare the $\delta^{13} \mathrm{C}$ and $\delta^{15} \mathrm{~N}$ values between 2 groups such as yellow and silver stage eels. Kruskal-Wallis nonparametric procedure was used to investigate the overall heterogeneity in the $\delta^{13} \mathrm{C}$ and $\delta^{15} \mathrm{~N}$ values among samples of the Japanese eel and among species. $t$-statistics for significance were used to test Pearson's correlation coefficient (r) between body length of fish samples and $\delta^{15} \mathrm{~N}$ values; $\mathrm{p}$-values $<0.05$ were considered statistically significant.

\section{RESULTS}

\section{Stable isotope signatures of the Japanese eel}

Dual plots of $\delta^{13} \mathrm{C}$ and $\delta^{15} \mathrm{~N}$ values of IPE and TPE individuals are shown in Fig. 2, and the summary of mean values are presented in Table 2. Japanese eels are characterized by large variation in both isotope ratios within and among samples. $\delta^{13} \mathrm{C}$ values of IPE ( $\mathrm{n}=$ 72 ) ranged from -24.9 to $-12.0 \%$ o (mean of $-17.0 \pm$ $3.4 \% \mathrm{SD}$ ), and $\delta^{15} \mathrm{~N}$ ranged from 6.5 to $18.4 \%$ (mean of $13.3 \pm 2.1 \%$ o). $\delta^{15} \mathrm{~N}$ values were independent of the body length in IPE $(r=0.078, p>0.1)$. A weak but significant

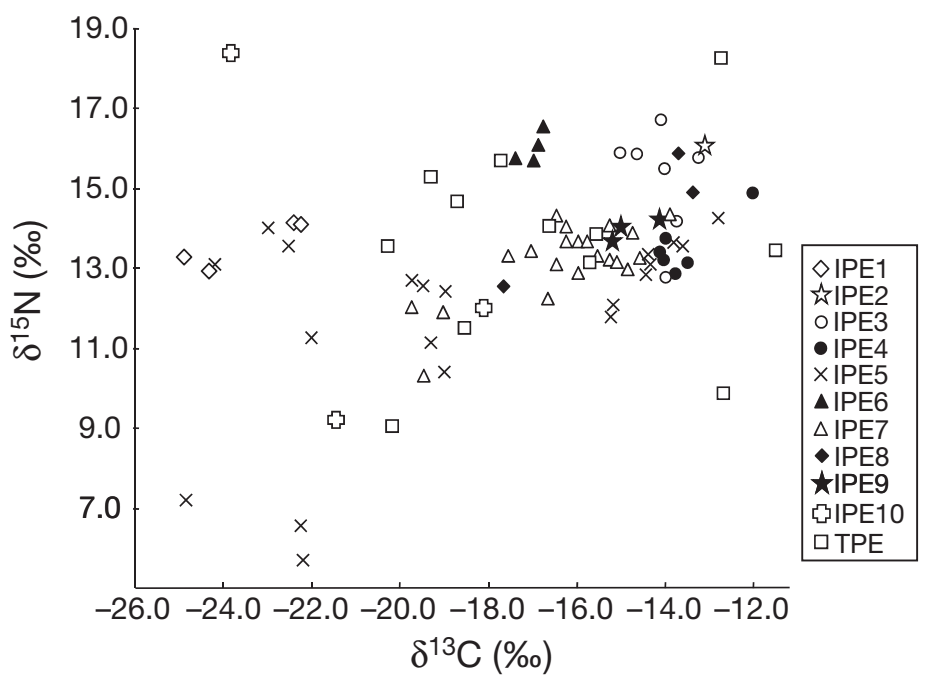

Fig. 2. Anguilla japonica. Dual plots of $\delta^{13} \mathrm{C}$ and $\delta^{15} \mathrm{~N}$ values of the initial phase eels (IPE) from 10 local samples and terminal phase eels (TPE). See Table 1 for the abbreviated locality ID 
Table 2. Anguilla japonica. Summary of mean values $( \pm \mathrm{SD})$ of $\delta^{13} \mathrm{C}$ and $\delta^{15} \mathrm{~N}$ values in adult Japanese eel samples. See Table 1 for ID information

\begin{tabular}{|lrcc|}
\hline \multicolumn{1}{l}{ ID } & $\mathrm{n}$ & $\delta^{13} \mathrm{C}$ & $\delta^{15} \mathrm{~N}$ \\
\hline IPE $^{\mathrm{a}}$ & 72 & $-17.0 \pm 3.4$ & $13.3 \pm 2.1$ \\
$\quad$ yellow & 37 & $-16.2 \pm 3.3$ & $13.6 \pm 1.9$ \\
silver & 35 & $-17.7 \pm 3.5$ & $13.0 \pm 2.3$ \\
\% & 41 & $-17.2 \pm 3.7$ & $13.4 \pm 2.6$ \\
$\mathrm{o}^{7}$ & 5 & $-14.3 \pm 0.6$ & $13.2 \pm 1.4$ \\
IPE1 & 4 & $-23.4 \pm 1.3$ & $13.6 \pm 0.6$ \\
IPE2 & 1 & -13.1 & 16.1 \\
IPE3 & 7 & $-14.1 \pm 0.6$ & $15.2 \pm 1.3$ \\
IPE4 & 6 & $-13.6 \pm 0.8$ & $13.5 \pm 0.7$ \\
IPE5 & 20 & $-18.6 \pm 4.0$ & $11.8 \pm 2.5$ \\
IPE6 & 4 & $-17.0 \pm 0.3$ & $16.0 \pm 0.4$ \\
IPE7 & 21 & $-16.3 \pm 1.6$ & $13.2 \pm 0.9$ \\
IPE8 & 3 & $-14.9 \pm 2.4$ & $14.5 \pm 1.7$ \\
IPE9 & 3 & $-14.8 \pm 0.6$ & $14.0 \pm 0.3$ \\
IPE10 & 3 & $-21.1 \pm 2.8$ & $13.3 \pm 4.7$ \\
TPE & 12 & $-16.6 \pm 3.1$ & $13.4 \pm 2.4$ \\
\% & 6 & $-16.4 \pm 3.7$ & $13.9 \pm 3.0$ \\
$0^{7}$ & 6 & $-16.9 \pm 2.6$ & $12.9 \pm 1.8$ \\
& & & \\
${ }^{a}$ All IPE samples were pooled & \\
\hline
\end{tabular}

difference was observed in $\delta^{13} \mathrm{C}$ between yellow $(-16.2$ $\pm 3.3, \mathrm{n}=37)$ and silver $(-17.7 \pm 3.5, \mathrm{n}=35)$ stages $(\mathrm{p}=$ $0.044)$, while differences in both $\delta^{13} \mathrm{C}$ and $\delta^{15} \mathrm{~N}$ values between 41 females and 5 males were not significant ( $p$ $>0.12$ ). Significant heterogeneity was detected in both $\delta^{13} \mathrm{C}$ and $\delta^{15} \mathrm{~N}$ values among 9 local samples (IPE1, IPE3-10: $\mathrm{p}<0.001$ ) and even among closely located 4 samples from Hamana Lake system (IPE3-6: p < 0.002). Heterogeneous $\delta^{13} \mathrm{C}$ values and the large variation within some samples indicate that the carbon pool system is heterogeneous among localities; some samples consisted of individuals from a number of different carbon pool systems. TPE $(n=12)$ also showed large variations in $\delta^{13} \mathrm{C}$ and $\delta^{15} \mathrm{~N}$ values, ranging from -20.5 to $-11.3 \%$ (mean of $-16.6 \pm$ $3.1 \%$ ) and 9 to $18.1 \%$ (mean of $13.4 \pm$ $2.4 \%$ ), respectively. No significant difference was observed in both $\delta^{13} \mathrm{C}$ and $\delta^{15} \mathrm{~N}$ values between sexes of TPE ( $\mathrm{p}>$ $0.4)$. Comparison among yellow and silver stages of IPE and TPE detected no significant difference in both $\delta^{13} \mathrm{C}$ and $\delta^{15} \mathrm{~N}$ values $(\mathrm{p}>0.12)$.

\section{Stable isotope ratios of mesopelagic fishes}

Dual plots of $\delta^{13} \mathrm{C}$ and $\delta^{15} \mathrm{~N}$ values of 10 marine fishes are shown in Fig. 3, and the summary of mean values are presented in Table 3. A very narrow range of $\delta^{13} \mathrm{C}$ values ( -17.6 to $-15.3 \%$ )

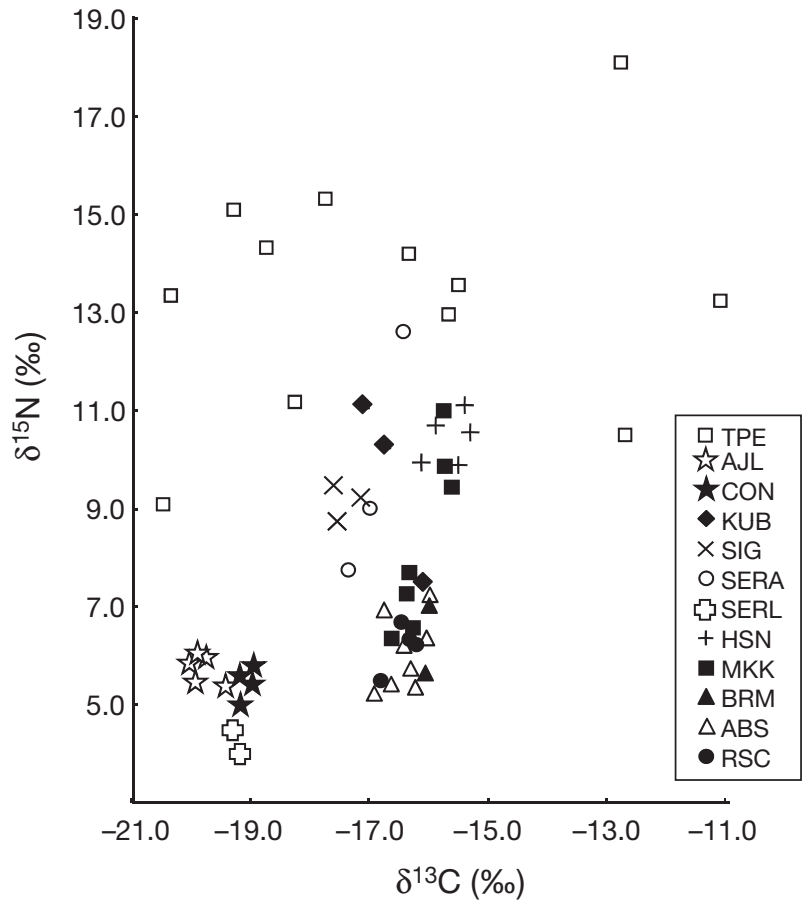

Fig. 3. Dual plots of $\delta^{13} \mathrm{C}$ and $\delta^{15} \mathrm{~N}$ values of 10 marine fishes. See Table 1 for the abbreviated species ID

was observed in 8 species of juvenile and adult mesopelagic fish (including 3 anguillid species), indicating that they belong to the same carbon pool system. The variance of $\delta^{13} \mathrm{C}$ values in these mesopelagic fishes was considerably smaller than that in TPE (F-test, p < $0.001)$. On the other hand, $\delta^{15} \mathrm{~N}$ values varied largely (5.2-12.6\%) among the mesopelagic species, and positive enrichment with body length was observed within species such as longneck eel (KUB: $r=0.976, p>0.1$ ),

Table 3. Summary of mean values $( \pm \mathrm{SD})$ of $\delta^{13} \mathrm{C}$ and $\delta^{15} \mathrm{~N}$ data in 10 marine fish species used in this study. See Table 1 for the location information

\begin{tabular}{|c|c|c|c|c|c|}
\hline Fish species & ID & Stage & $\mathrm{n}$ & $\delta^{13} \mathrm{C}$ & $\delta^{15} \mathrm{~N}$ \\
\hline \multicolumn{6}{|l|}{ Anguilliformes } \\
\hline Anguilla japonica & AJL & Larva & 5 & $-19.8 \pm 0.2$ & $5.7 \pm 0.3$ \\
\hline Conger sp. & $\mathrm{CON}$ & Larva & 4 & $-19.1 \pm 0.1$ & $5.4 \pm 0.3$ \\
\hline Derichthys sp. & KUB & Adult & 3 & $-16.6 \pm 0.5$ & $9.7 \pm 1.9$ \\
\hline Nemichthys sp. & SIG & Adult & 3 & $-17.4 \pm 0.2$ & $9.2 \pm 0.4$ \\
\hline Serrivomer sp. & SERA & Adult & 3 & $-16.9 \pm 0.5$ & $9.8 \pm 2.5$ \\
\hline Serrivomer sp. & SERL & Larva & 3 & $-19.2 \pm 0.1$ & $4.2 \pm 0.3$ \\
\hline \multicolumn{6}{|l|}{ Aulopiformes } \\
\hline Dolichosudis fuliginosa & $\mathrm{HSN}$ & Adult & 5 & $-15.7 \pm 0.4$ & $10.4 \pm 0.5$ \\
\hline \multicolumn{6}{|l|}{ Perciformes } \\
\hline Emmelichthys struhsakeri & RSC & Juvenile & 4 & $-16.5 \pm 0.2$ & $6.1 \pm 0.5$ \\
\hline Lepidocybium flavobrunneum & ABS & Juvenile & 8 & $-16.4 \pm 0.3$ & $6.0 \pm 0.7$ \\
\hline Ruvettus pretiosus & BRM & Juvenile & 2 & $-16.0 \pm 0.0$ & $6.3 \pm 1.0$ \\
\hline Scombrolabrax heterolepis & MKK & Juvenile & 7 & $-16.1 \pm 0.4$ & $8.3 \pm 1.8$ \\
\hline
\end{tabular}


sawtooth eel (SERA: $r=0.941, p>0.1$ ) and longfin escolar (MKK: $r=0.971, p<0.001$ ), indicating different trophic levels by species and developmental stages. Anguillid leptocephali (AJL, CON and SERL) represented a further depleted and narrow range of $\delta^{13} \mathrm{C}$ $(-20.0$ to $-19.0 \%)$ and $\delta^{15} \mathrm{~N}(4.0-6.0 \%)$ values. Therefore, mesopelagic species at juvenile and larval stages and those showing positive enrichment of $\delta^{15} \mathrm{~N}$ with body length were not included in subsequent statistic analysis, and significant heterogeneity among HSN, SIG and TPE was observed $(p=0.007)$.

\section{DISCUSSION}

Harrod et al. (2005) found much more depleted $\delta^{13} \mathrm{C}$ values $(-23.6 \%$ average) in European eels $(>30 \mathrm{~cm}$ in body length) collected in the freshwater habitat than those in the marine habitat ( $-16.3 \%$ average). Likewise, Bardonnet \& Riera (2005) observed a significant shift of isotopic signatures from marine glass eels to river pigmented eels, where the pigmented eels, after starting to assimilate terrigenous organic matter sources, were observed to have lower $\delta^{13} \mathrm{C}(-26.7$ to $-22.7 \%$ ) than the marine glass eels $(-21.4 \pm 0.3 \%$ o) Thus, the large $\delta^{13} \mathrm{C}$ variation of IPE observed in the present study may correspond to the relative extent of assimilation of marine and terrigenous organic matter. The silver stage IPE with depleted $\delta^{13} \mathrm{C}$ may have ceased feeding in the freshwater habitat; those with elevated $\delta^{13} \mathrm{C}$ did so in habitats with greater marine influence (i.e. in estuarine or coastal areas).

Based on the stomach content analysis in shortfin eel Anguilla australis of Lake Ellesmere, Ryan (1986) observed that smaller eels $(\leq 40 \mathrm{~cm})$ fed primarily on invertebrates and became progressively more piscivorous as they grew; large eels $(>50.1 \mathrm{~cm})$ were almost entirely piscivorous. Kelly \& Jellyman (2007) observed a similar diet shift in shortfin eel, with progressive enrichment of the $\delta^{15} \mathrm{~N}$ value. Since no such correlation between body length and $\delta^{15} \mathrm{~N}$ value was observed in the present study, the individual eels used may already have been too large to influence the $\delta^{15} \mathrm{~N}$ value any further. The large $\delta^{15} \mathrm{~N}$ variation in IPE indicates that the trophic level of eels may vary among localities and that individual eels may consume diverse food sources within a locality. Although $\delta^{15} \mathrm{~N}$ of TPE was higher than that of adult mesopelagic species and comparable with values reported for sharks, swordfish and tunas (Estrada et al. 2005, MacNeil et al. 2005, Ménard et al. 2007), it is unlikely that TPE share a similar trophic level with these top marine predators.

The large variation observed in both isotope ratios of IPE appears to be inherited by TPE. If the silver eels have assimilated marine nutrition, isotopic signatures of TPE would have markedly shifted downward in $\delta^{15} \mathrm{~N}$ and been skewed in $\delta^{13} \mathrm{C}$. Yet, isotopic fractionation and turnover rates may vary considerably among species (Suring \& Wing 2009), and turnover rates of migrating eels may be low as suggested by the low metabolic rate experimentally indicated by Van Ginneken et al. (2005). However, Suring \& Wing (2009) observed isotope turnover in blue cod Parapercis colias to be comparable with other fish species, although the growth rate of the blue cod was much slower than the fish used in previous studies. Furthermore, the long oceanic spawning migration required about half a year for the Japanese eel (Tsukamoto et al. 2003) which would be enough to yield a significant shift in the isotopic signature between IPE and TPE. Thus, the almost identical profiles in the stable isotopic values between IPE and TPE indicate that the Japanese eels during the spawning migration do not assimilate marine food sources, keeping the initial isotopic signatures obtained at the habitat where they ceased feeding.

Investigating otolith strontium and calcium $(\mathrm{Sr}: \mathrm{Ca})$ ratios, Tsukamoto et al. (1998) suggested that most silver stage Japanese eels caught in the coastal areas of Japan were 'sea eels' (spending most of their life in the sea without entering freshwater areas). Subsequently using a larger sample size, Tsukamoto \& Arai (2001) and Chino \& Arai (2009) observed 3 types of silver eels; 'sea eels', 'estuarine eels' (inhabiting estuaries or switching between different habitats), and 'river eels' (remaining in freshwater river habitats after arrival in the estuary), in which they found 'estuarine eels' to be the most predominated type (>50\%) followed by 'sea eels' and 'river eels'. These results derived from $\mathrm{Sr}: \mathrm{Ca}$ data may be corroborated by our $\delta^{13} \mathrm{C}$ data showing that many of our silver eels had intermediate $\delta^{13} \mathrm{C}$ value (Fig. 4). Furthermore, the similarly scattered $\delta^{13} \mathrm{C}$ data profiles of IPE and TPE indicate that eels from different habitats are successfully contributing to the reproduction.

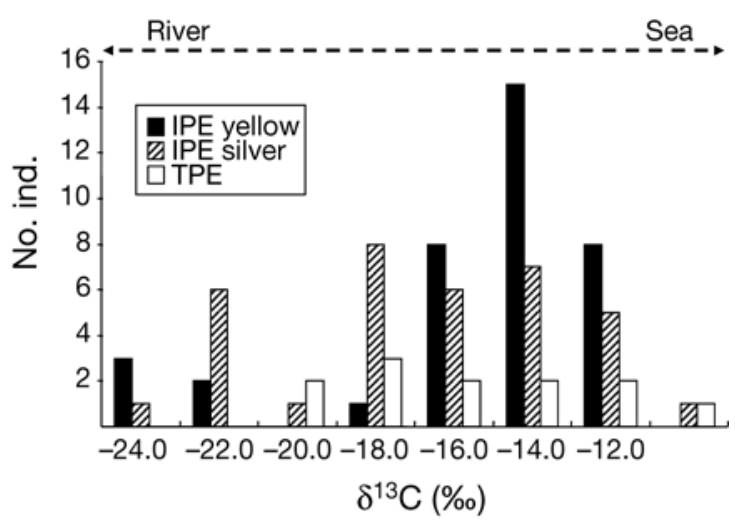

Fig. 4. Anguilla japonica. $\delta^{13} \mathrm{C}$ values of yellow and silver stages of initial (IPE) and terminal phase eels (TPE) 
Acknowledgements. We are indebted to captain N. Nagai of RV Kaiyo-Maru and Captain S. Toishi of RV Hokko-Maru and their crew members, for their invaluable support in the research cruise. We also thank S. Watanabe (Japan International Research Center for Agricultural Sciences) for his kind reading of this manuscript, and T. Kawashima and C. Takahashi (National Research Institute of Fisheries Science) for their technical assistance in stable isotope analysis. This work was supported in part by grants from the Ministry of Agriculture, Forestry, and Fisheries of Japan and Fisheries Research Agency, Japan.

\section{LITERATURE CITED}

Aoyama J (2009) Life history and evolution of migration in catadromous eels (genus Anguilla). Aqua-BioSci Monogr $2: 1-42$

Bardonnet A, Riera P (2005) Feeding of glass eels (Anguilla anguilla) in the course of their estuarine migration: new insights from stable isotope analysis. Estuar Coast Shelf Sci 63:201-209

$>$ Chino N, Arai T (2009) Relative contribution of migratory type on the reproduction of migrating silver eels, Anguilla japonica, collected off Shikoku Island, Japan. Mar Biol 156:661-668

Chow S, Kurogi H, Mochioka N, Kaji S, Okazaki M, Tsukamoto K (2009) Discovery of mature freshwater eels in the open ocean. Fish Sci 75:257-259

Dollerup J, Graver CM (1985) Repeated induction of testicular maturation and spermiation, alternating with periods of feeding and growth in silver eel, Anguilla anguilla (L.). Dana 4:19-39

Durif C, Dufour S, Elie P (2005) The silvering process of Anguilla anguilla: a new classification from the yellow resident to the silver migrating stage. J Fish Biol 66: 1025-1043

Estrada JA, Lutcavage M, Thorrold SR (2005) Diet and trophic position of Atlantic bluefin tuna (Thunnus thynnus) inferred from stable carbon and nitrogen isotope analysis. Mar Biol 147:37-45

Folch J, Lees M, Stanley GHS (1957) A simple method for the isolation and purification of total lipids from animal tissue. J Biol Chem 226:497-509

Harrod C, Grey J, McCarthy TK, Morrissey M (2005) Stable isotope analyses provide new insights into ecological plasticity in a mixohaline population of European eel. Oecologia 144:673-683

Kelly DJ, Jellyman DJ (2007) Changes in trophic linkages to shortfin eels (Anguilla australis) since the collapse of submerged macrophytes in Lake Ellesmere, New Zealand. Hydrobiologia 579:161-173

MacNeil MA, Skomal GB, Fisk AT (2005) Stable isotopes from

Editorial responsibility: Ivan Nagelkerken,

Nijmegen, Netherlands multiple tissues reveal diet switching in sharks. Mar Ecol Prog Ser 302:199-206

Ménard F, Lorrain A, Potier M, Marsac F (2007) Isotopic evidence of distinct feeding ecologies and movement patterns in two migratory predators (yellowfin tuna and swordfish) of the western Indian Ocean. Mar Biol 153: 141-152

Okamura A, Yamada Y, Yokouchi K, Horie N and others (2007) A silvering index for the Japanese eel Anguilla japonica. Environ Biol Fishes 80:77-89

> Pankhurst NW, Sorensen PW (1984) Degeneration of the alimentary-tract in sexually maturing European Anguilla anguilla (LeSueur). Can J Zool 62:1143-1149

$>$ Ryan PA (1986) Seasonal and size-related changes in the food of the short-finned eel, Anguilla australis in Lake Ellesmere, Canterbury, New Zealand. Environ Biol Fishes 15: $47-58$

Suring E, Wing SR (2009) Isotopic turnover rate and fractionation in multiple tissues of red rock lobster (Jasus edwardsii) and blue cod (Parapercis colias): consequences for ecological studies. J Exp Mar Biol Ecol 370:56-63

> Svedäng H, Wickström H (1997) Low fat contents in female silver eels: indications of insufficient energetic stores for migration and gonadal development. J Fish Biol 50: $475-486$

Tsukamoto K (2006) Spawning of eels near a seamount. Nature 439:929

Tsukamoto K (2009) Oceanic migration and spawning of anguillid eels. J Fish Biol 74:1833-1852

Tsukamoto K, Arai T (2001) Facultative catadromy of the eel Anguilla japonica between freshwater and seawater habitats. Mar Ecol Prog Ser 220:265-276

Tsukamoto K, Nakai I, Tesch WV (1998) Do all freshwater eels migrate? Nature 396:635-636

Tsukamoto K, Aoyama J, Miller MJ (2002) Migration, speciation, and the evolution of diadromy in anguillid eels. Can J Fish Aquat Sci 59:1989-1998

Tsukamoto K, Lee TW, Fricke H (2003) Spawning area of the Japanese eel. In: Aida K, Tsukamoto K, Yamauchi K (eds) Eel biology. Springer-Verlag, Tokyo, pp 121-140

> Van Ginneken V, Van den Thillart G (2000) Eel fat stores are enough to reach the Sargasso. Nature 403:156-157

> Van Ginneken V, Antonissen E, Müller UK, Booms R, Eding E, Verreth J, Van den Thillart G (2005) Eel migration to the Sargasso: remarkably high swimming efficiency and low energy costs. J Exp Biol 208:1329-1335

Van Ginneken V, Dufour S, Sbaihi M, Balm P and others (2007) Does a 5500-km swim trial stimulate early maturation in the European eel (Anguilla anguilla L.)? Comp Biochem Physiol Part A 147:1095-1103

Westin L (1990) Orientation mechanisms in migrating European silver eel (Anguilla anguilla): temperature and olfaction. Mar Biol 106:175-179

Submitted: September 9, 2009; Accepted: December 2, 2009 Proofs received from author(s): February 18, 2010 